\title{
Implementasi Kurikulum 2013 Pada Mata Pelajaran Aqidah Akhlak Bagi Siswa Kelas VIII Di Madrasah Tsanawiyah Nurul Hikmah Barupring
}

\author{
Haerudin'1), Adi Purwati ${ }^{2)}$ \\ Pendidikan Guru Sekolah Dasar, FKIP, Universitas Buana Perjuangan Karawang \\ JI HS. Ronggo Waluyo, Puseurjaya, Telukjambe Timur, Karawang, Jawa Barat, \\ Indonesia
}

Corresponding author's: haerudin@ubpkarawang.ac.id

\section{Implementation of Curriculum 2013 At Aqeedah Morals Lesson For Students In Class VIII MTs Nurul Hikmah Barupring}

\section{Article info: \\ Article History \\ Available online \\ 30 September 2018}

Keywords:

Implementation,

Curriculum 13.

Aqidah Akhlak,

Students.

\begin{abstract}
Abstrak
Mata pelajaran pendidikan agama Islam adalah salah satu bagian penting dari sistem pendidikan di Indonesia, agar menjadi manusia yang beriman dan bertaqwa kepada Tuhan YME serta berakhlakul karimah. Mata pelajaran Aqidah akhlak merupakan salah satu mata pelajaran yang apabila diterapkan dengan baik dan benar mampu memberikan dampak bukan hanya pengetahuan saja namun berhubungan dengan sikap, keterampilan dan pengetahuan kepada pesert didik. Untuk mewujudkan tujuan dan fungsi dari mata pelajaran Akidah Akhlak, tentu seorang pendidik memerlukan suatu cara atau metode seperti yang pemerintah cetuskan untuk kemajuan pendidikan yaitu kurikulum 2013. Ketika suatu sekolah ataupun seorang pendidik minim pengetahuan mengenai informasi yang berkaitan dengan kemajuan dalam pendidikan, maka, suatu sekolah dan gurupun tidak akan mampu menciptakan generasi-generasi seperti yang pemerintah harapkan. Tujuan dari penelitian ini untuk memperoleh data tentang perencanaan pembelajaran Akidah Akhlak menurut kurtilas di MTs Nurul Hikmah Barupring Brebes, untuk memperoleh data tentang pelaksanaan pembelajaran Akidah Akhlak menurut kurtilas di MTs Nurul Hikmah Barupring Brebes dan untuk memperoleh data tentang evaluasi pembelajaran Akidah Akhlak menurut kurtilas di MTs Nurul Hikmah Barupring Brebes.Penelitian ini bertitik tolak pada implementasi kurtilas pada mapel Akidah Akhlak. Implementasi kurtilas ini dibutuhkan oleh setiap guru untuk meningkatkan kualitas pendidik dan peserta didik yang jauh lebih baik. Adapun metodologi penelitian ini dilakukan dengan teknik pengumpulan data berdasarkan sumbernya yakni melalui wawancara, observasi dan dokumentasi serta data kepustakaan yang berkaitan dengan kurtilas dan mata pelajaran Akidah Akhlak pendekatan yang digunakan yakni, kualitatif deskriptif. Berdasarkan hasil data tersebut di atas, bahwa perencanaan pembelajaran Akidah Akhlak menurut kurtilas di MTs Nurul Hikmah Barupring Brebes, Guru dapat menyiapkan silabus dan RPP, pelaksanaan pembelajaran Akidah Akhlak menurut kurtilas di MTs Nurul Hikmah Barupring
\end{abstract}




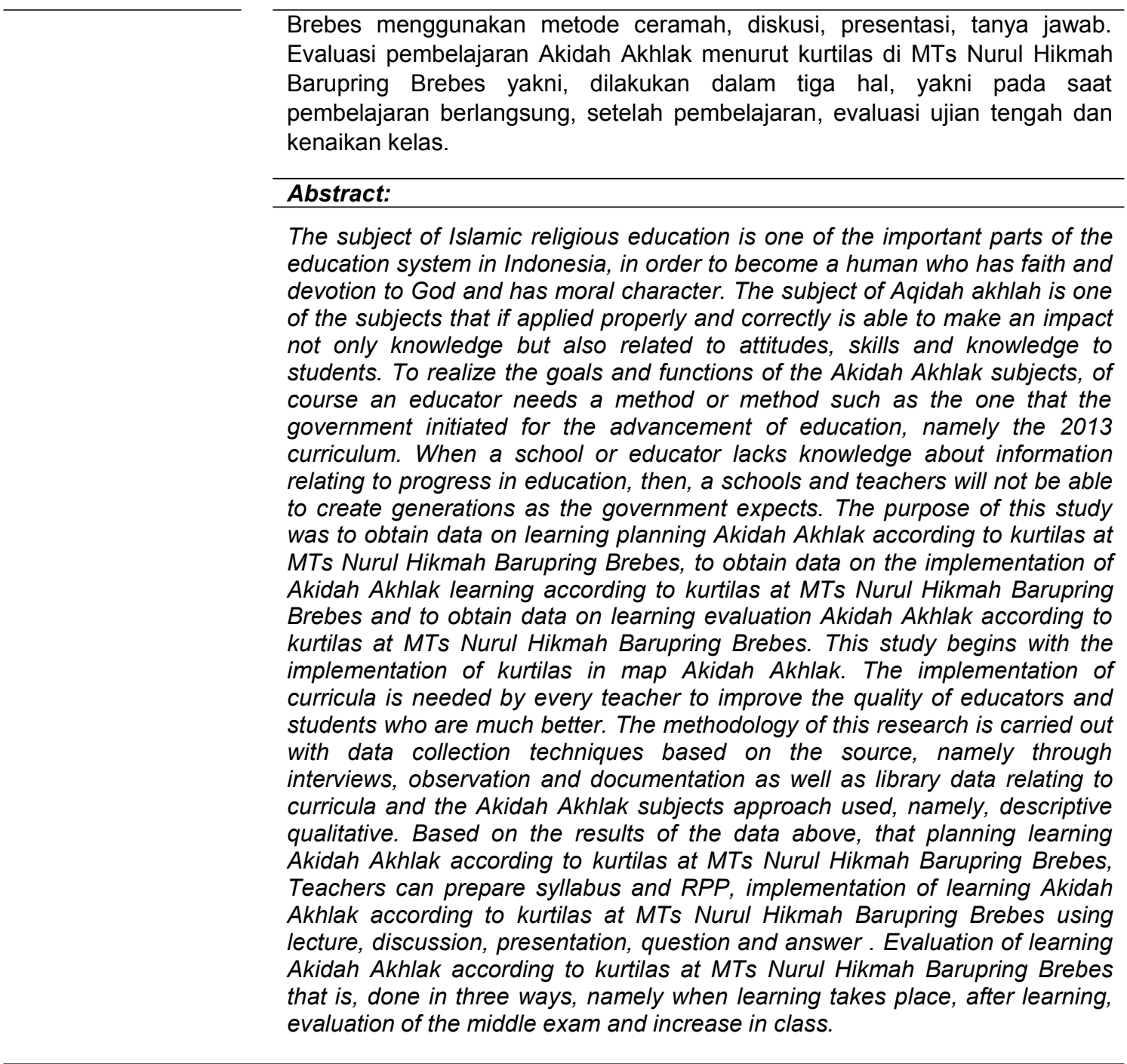

\section{PENDAHULUAN}

Dalam upaya pemerintah untuk menyempurnakan mutu pendidikan di Indonesia, pemerintah seringkali mengubah kurikulum agar menjadi lebih baik lagi. Perkembangan Kurikulum di Indonesia sudah mengalami banyak perubahan sebelum tahun 1945, mulai dari kurikulum 1985 yang berlaku sampai akhir 1993, kurikulum 1994 yang berlaku sampai akhir 1996, revisi kurikulum 1994 yang berlaku sampai akhir 2003, rintisan kurikulum berbasis kompetensi (KBK) yang berlaku sampai akhir 2005, kurikulum tingkat satuan pendidikan (KTSP) yang berlaku sampai akhir2012, hingga kurikulum 2013 yang sedang dijalankan saat ini. Menurut beberapa pakar, perubahan kurikulum dari masa ke masa, baik di Indonesia maupun di negara lain disebabkan karena kebutuhan masyarakat yang setiap tahunnya selalu berkembang dan tuntutan zaman yang cenderung berubah. Oleh karena itu, kurikulum yang baik akan sangat diharapkan dapat dilaksanakan di Indonesia sehingga akan menghasilkan masa depan anak bangsa yang cerah yang berimplikasi pada kemajuan bangsa dan Negara (Cahaya Kusuma, 2013: 12). 
Tujuan dari penggagasan kurikulum 2013 sendiri untuk mendorong peserta didik, mampu lebih baik dalam melakukan observasi, bertanya, bernalar, dan mengkomunikasikan (mempresentasikan). Hasil yang diinginkan pemerintah dari kurikulum yang baru ini agar supaya peserta didik memiliki kompetensi sikap, ketrampilan, dan pengetahuan jauh lebih baik. Mereka akan lebih kreatif, inovatif, dan lebih produktif. Melalui Kurikulum 2013 ingin ditingkatkan dan diseimbangkan antara kompetensi sikap (attitude), keterampilan (skill), dan pengetahuan (knowledge) di kalangan peserta didik. sehingga nantinya para lulusan yang lahir dari penerapan Kurikulum 2013, dapat menjadi lulusan yang lebih berkualitas dan mampu bersaing di dunia internasional dengan basis karakter yang kuat(Muhammad Nuh dkk, 2013:7).

Mata pelajaran Pendidikan Agama Islam Aqidah Akhlak adalah salah satu bagian penting dari sistem pendidikan di Indonesia untuk mencapai tujuan pendidikan nasional agar membentuk peserta didik menjadi manusia yang berima dan bertaqwa kepada Tuhan YME serta berakhlak mulia, oleh karena itu, pembelajaran aqidah akhlak tentang menghayati dan mengimani Allah SWT serta merealisasikan pada perilaku akhlak mulia dalam kehidupan sehari-hari dengan bentuk sikap berbudi pekerti luhur dan bermartabat serta beriman dan bertaqwa kepada Tuhan menjadi sangatlah penting.

Melewati proses pembelajaran yang mengutamakan tentang penanaman nilainilai Islam, dengantidak melupakan etika sosial melalui pendekatan saintifik. Untuk itu penulis sangat tertarik bagaimana pembelajaran aqidah akhlak ini diimplementasikan dengan kurikulum 2013. Pengimplementasian kurikulum 2013 pada lembaga pendidikan. Terutama pada Madrasah Tsanawiyah seperti Madrasah Tsanawiyah Nurul Hikmah Barupring dimana sekolah tersebut memiliki keunikan yakni sekolah yang dibawah naungan Kementerian Agama ini merupakan salah satu sekolah swasta yang mampu menerapkan kurikulum 2013 dengan baik, meski sekolah tersebut masih banyak kekurangan terutama dalam hal fasilitas yang memadai, tenaga pengajar yang terbatas, serta peserta didik yang memiliki kemampuan rata-rata yang standar namun justru hal tersebut tidak menjadi penghalang untuk tetap bisa menjalankan kurikulum 2013 dengan baik.

MTs Nurul Hikmah ini bisa menjadi contoh untuk sekolah swasta yang lain yang memiliki keterbatasan baik dalam segi fasilitas, tenaga pengajar hingga peserta didik untuk memacu, memberi semangat dan kepercayaan diri suatu sekolah untuk mengimplementasikan kurikulum 2013. Oleh karena itu penulis merasa terpanggil untuk melakukan penelitian yang berjudul "Implementasi Kurikulum 2013 Pada Mata Pelajaran Aqidah Akhlak Bagi Siswa Kelas VIII Di Madrasah Tsanawiyah Nurul Hikmah Barupring".

\section{METODE PENELITIAN}

Penelitian ini menggunakan pendekatan kualitatif deskiptif. Penelitian kualitatif adalah penelitian yang bermaksud untuk memahami fenomena tentang apa yang dialami oleh subjek penelitian misalnya perilaku, persepsi, motivasi, tindakan, dan lain- 
lain, secara holistik, dan dengan cara deskripsi dalam bentuk kata-kata dan bahasa, pada suatu konteks khusus yang alamiah dan dengan memanfaatkan berbagai metode alamiah (Lexy. J. Moloeng, 2004: 6) Penelitian ini bertujuan untuk mendapatkan data/ gambaran yang objektif, faktual, akurat, dan sistematis, mengenai masalah yang akan dikaji oleh peneliti (Lexy. J. Moloeng, 2004: 5). Penelitian ini digunakan untuk mendeskripsikan tentang segala sesuatu yang berkaitan dengan implementsi kurikulum 2013 pada mata pelajaran aqidah akhlak bagi siswa kelas VIII MTs Nurul Hikmah.

Jenis data dalam penelitian ini adalah data berdasarkan sumbernya yakni melalui wawancara, observasi, dan dokumentasi, adapun sumber data alam melakukan penelitian ini data-data yang diperlukan yaitu data yang diperoleh dari sumbernya secara langsung diamati dan dicatat secara langsung. seperti, wawancara, observasi, dan dokumentasi dengan pihak yang terkait, khususnya kepala sekolah itu sendiri serta beberapa informan lainnya seperti waka kurikulum, Guru aqidah akhlak dan siswa-siswi kelas VIII MTs Nurul Hikmah. Pemilihan informan dalam penelitian ini dilakukan dengan cara atau teknik snow sampling, yaitu informan kunci akan menunjuk seseorang yang mengetahui masalah yang akan diteliti untuk melengkapi keterangan, dan orang yang ditunjuk tersebut akan menunjuk orang lain lagi bila keterangan yang diberikan kurang memadai.

\section{HASIL PENELITIAN DAN PEMBAHASAN}

K-13 yang diterapkan di MTs Nurul Hikmah. Pada dasarnya, MTs Nurul Hikmah menerapkan kurikulum 2013 pada tahun pertama yang diberlakukan hanya untuk kelas VII atas intruksi dari kementerian agama untuk tetap melanjutka bagi sekolah yang telah melaksanakan k-13 selama satu semester, termasuk kelas VIII yang dijadikan objek oleh peneliti.

Berikut petikan wawancara dengan kepala sekolah MTs Nurul Hikmah, yakni bapak Drs. H. Nurkholis, M. Pd. I mengatakan bahwa: "Intruksi dari dinas pendidikan adalah bagi lembaga pendidikan yang baru mengimplementasikan kurikulum 2013 hanya satu semester maka di anjurkan untuk kembali menjadi KTSP, dan sesuai dengan intruksi dari pemerintah yakni dari reding cektor kami kementrian agama, intruksi dari kementrian agama kita menggunakan kurikulum 2013 kita lanjutkan yang sudah kita laksanakan selama satu semester, jadi kita lanjutkan pelaksanaannnya. Karena resmi ada suratnya dan sudah di tunjang sejak awal dengan sosialisasi, pelatihan-pelatihan, diklat-diklat bahkan yang lebih ada TOT, bahkan juga buku siswa dan buku gurunya sudah jadi. Nah,,ini salah satu kelebihannya,, jadi dalam pelaksanaan pembelajaran sudah sedikit melegakan karena untuk buku siswa mapel agama yang kurikulum 2013 dengan pendekatan saintific sudah tersedia termasuk buku aqidah akhlak sedangkan buku mapel umum belum tersedia.begitu saya kirakira" (Nurkholis, Kepala Sekolah MTs Nurul Hikmah, Wawancara terbuka, Tonjong 23 Oktober 2017).

Kurikulum 2013 merupakan kurikulum pelengkap KTSP dimana dalam kurikulum 2013 terdapat perubahan yang mencolok terkait pendekatan yang dipakai lebih 
bersifat ilmiah serta penilaian autentik yang lebih akurat, hal baru tersebut membuat guru guru sulit untuk menerapkan dikarenakan metode yang biasa dipakai adalah metode KTSP dan sulit untuk merubah suatu kebiasaan. Hal tersebut sependapat juga diungkapkan oleh guru maple akidah akhlak yakni:

"Dalam pelaksanaannya (kurikulum 2013), sebenarnya membutuhkan kerja ekstra karena kurikulum ini merupakan kurikulum yang baru bagi kami MTs Nurul Hikmah jadi seringkali para guru merasa kesulitan dalam mengimpementasikan kurikulum 2013, sehingga sangat perlu diperkenalkan berulang kali kepada guru. Yang seringkali menjadi kesulitan para guru adalah penyusunan RPP, mengkondisikan kelas dengan pendekatan saintific serta penilaiannya. Memang kita akui, metode yang dipakai ya, ini itu saja monoton kebanyakan ceramah. Dan merubah kebiasaan guru-guru memakai metode lama menjadi metode yang lebih modern itu susah mbak" (Munisah, Guru akidah akhlak MTs Nurul Hikmah, Wawancara nonformal, Tonjong, 23 Oktober 2017).

Sedangkan hasil observasi yang dibuat dalam bentuk catatan oleh penulis ketika penulis mengikuti kegiatan belajar mengajar terkait materi ananiyah, ghadab, putus asa dan tamak, di kelas VIII B pada jam ke tiga pada dua kali pertemuan $2 \times 40$ menit dijabarkan sebagai berikut:(Observasi pertama di kelas VIII B, Selasa, 24 Oktober 2017).

Metode merupakan jembatan penghubung antara materi dan pemahaman siswa terkait materi tersebut, dalam pemilihan metode harus didasarkan pada karakteristik siswa, materi, sarana prasarana dan alokasi waktu yang dibutuhkan. Dalam pembelajran aqidah akhlaq khususnya materi akhlaq tercela yakni ananiyah, putus asa, ghadab dan tamak, guru mata pelajaran aqidah akhlaq kelas VIII B MTs Nurul Hikmah melakukan metode ceramah, metode diskusi, metode tanya-jawab dan bermain peran (Role Playing). Sesuai dengan pendapat bu Munisah, S. Pd. I beliau selaku salah satu pengampuh mata pelajaran aqidah akhlak di MTs Nurul Hikmah, sebagai berikut:

"Dalam pembelajaran aqidah akhlak dikelas VIII, saya menggunakan metode yang saya sesuaikan dengan karakteristik anak, materi dan sarana. Memang lebih banyak metode berdiskusi, presentasi, ceramah dan model pembelajaran yang digunakan dalam kompetensi ini adalah role playing. Dalam proses saya menggunakan media papan tulis, karena lebih efisien yakni anak-anak lebih fokus, saya tidak mennggunaan proyektor karena masih sangat minim sekali fasilitas yang seperti itu untuk di MTs Nurul Hikmah ini" (Munisah, Guru Akidah Akhlak kls VIII B, MTs Nurul Hikmah, Wawancara pribadi, Tonjong, 14 November 2017).

Pernyataan tersebut didukung oleh salah satu siswa kelas VIII B Muhammad AlFaris sebagai berikut: "Pembelajaran aqidah akhlaq menyenangkan mbak, pertemuan kemarin diskusi dan ceramah, sekarang dengan bermain peran kita sekelompok harus sama-sama aktif, saling kerjasama agar perannya bagus. Kita jadi faham perilaku ananiyah, putus asa,ghadhab dan tamak'. Setiap kelompok dalam memberikan contoh lain mengenai sikap ananiyah, putus asa, ghadhab dan tamak bagus-bagus. Semisal tadi kelompok satu ada yang mencontohkan seorang murid yang tidak mau piket pada 
hari piketnya ketika diingatkan malah dia marah-marah kepada temannya, ini merupakan contoh terdekat kami di dalam kelas, sehingga akan sangat mudah untuk mengingat kembali sikap pemarah yang merupakan salah satu sikap tercela yang harus kita hindari" (M. Al-Faris, salah satu murid kls VIII B MTs Nurul Hikmah, Wawancara terbuka, Tonjong, 14 November 2017).

Dalam pelaksanaan pembelajaran Akidah Akhlak Bapak Nurrohman, S. Pd. I berpendapat bahwa: "Dalam proses pelaksanaan pembelajaran KTSP dan kurikulum 2013 terlihat perbedaan yang mencolok, dulu KTSP hanya menitik beratkan bagaiimana anak bisa pandai dalam bidang akademik, sedangkang kurikulum 2013 selain anak diharapkan pandai dalam akademiknya, juga harus pandai dalam bersikap dan memiliki keterampilan. Oleh sebab itu, penanaman karakter lebih banyak dikaji disini melalui $5 \mathrm{M}$ yang sudah ditentukan oleh pemerintah" (Nurrohman, Guru Akidah Akhlak MTs Nurul Hikmah, Wawancara nonformal, Tonjong, 15 November 2017).

Tidak dapat dipungkiri bahwasannya dalam pelaksanaan pembelajaran aqidah akhlak guru lebih dominan menggunaka metode ceramah, ini karena materi yang disampaikan mengharuskan guru untuk memakai metode ceramah. Guru harus menjelaskan terkait aqidah serta memberikan contoh-contoh terkait akhlak yang baik dan yang buruk dalam kehidupan sehari-hari.

Dalam metode yang digunakan oleh bapak Nurrohman, S. Pd. I, beliau berpendapat bahwa: "Sehubungan dengan metode yang saya pakai dalam pembelajaran aqidah akhlaq kemarin lebih kepada metode ceramah mbak. Namun yang pro aktif, jadi saya ceramah sambil memberikan rangsangan kepada murid saya agar siswa-siswi saya mau untuk berfikir" ( Nurrohman, Guru Akidah Akhlak MTs Nurul Hikmah, Wawancara nonformal, Tonjong, 15 November 2017).

Akan tetapi model ceramah yang digunakan oleh guru MTs Nurul Hikmah ini adalah model pro aktif dimana guru memberikan rangsangan agar siswa dapat berfikir. Dalam bermain peran (Role Playing) pada mata pelajaran aqidah akhlaq dikelas VIII MTs Nurul Hikmah, bertujuan untuk mengeksplorasi perasaan peserta didik, mentransfer dan mewujudkan mengenai perilaku nilai dan perspepsi peserta didik, mengembangkan keterampilan (Skill) dalam pemecahan masalah dan mengeksplorasi materi pelajaran dengan bervariasi.

Tahap selanjutnya setelah perencanaan dan pelaksanaan pembelajaran adalah evaluasi pembelajaran. Dalam penilain kurikulum 2013 ini sangat berbeda dengan penilain sebelumnya karena penilain yang dipakai oleh kurikulum 2013 adalah penilaian otentik.

Dalam wawancara yang saya lakukan dengan bapak Nur Kholis, M. Pd. I terkait prinsip-prinsip dalam penilaian hasil belajar siswa sangat relevan dengan Buku guru aqidah akhlaq terbitan Kemenag, yakni (Kemenag, 2014: 14).

1. Objektif, berarti penilain berbasis standart penilain dan tidak dipengaruhi faktor subjektifitas penilai. 
2. Terpadu, penilaian oleh pendidik dilakukan secara terencana, menyatu dalam kegiatan pembelajaran yang dilakukan secara berkesinambungan.

3. Ekonomis, penilaian yang dilakukan efisien dan efektif dalam perencanaan, pelaksanaan dan pelaporannya.

4. Transparan, prosedur penilaian, kriteria penilaian, dan dasar pengambilan keputusan dapat diakses oleh semua pihak.

5. Akuntabel, penilaian dapat dipertanggung jawabkan kepada pihak internl sekolah maupun eksternal untuk aspek teknik, prosedur dan hasilnya.

6. Edukatif, mendidik dan memotivasi peserta didik dan pendidik

Terdapat tiga aspek yang dinilai di MTs Nurul Hikmah dalam kurikulum 2013 yaitu aspek sikap (Afektif), pengetahuan (Kognitif) dan keterampilan(psikomotori). Ketiga aspek tersebut memiliki teknik dan instrumen yang berbeda-beda. Mulai dari penilaian aspek sikap (sosial dan spiritual) menggunakan teknik observasi, penilaian diri, penilaian teman sejawat, dan jurnal. Sedangkan untuk penilaian aspek pengetahuan menggunakan instrumen tes tulis maupun lisan dan penugasan. Dan penilaian keterampilan menggunakan tes praktik, proyek dan portofolio. Setiap teknik dan instrumen memiliki format dan penskoran masing-masing.

Hal tersebut juga diungkapkan oleh bapak kepala sekolah MTs Nurul Hikmah yakni bapak Nurkholis, M. Pd. I sebagai berikut: "Dalam menilai hasil belajar yang dilakukan oleh peserta didik itu ada prinsipnya mbak, penilaian yang dilakukan harus sesuai dengan standart penilaian, dilakukan secara terencana dan berkesinambungan jadi terus-terus dilakukan, penilaiannya juga harus efektif dan efisien" (Nurkholis, Kepala Sekolah MTs Nurul Hikmah, Wawancara terbuka, 23 Oktober 2017).

Dalam penilaian kurikulum 2013 yang diterapkan di MTs Nurul Hikmah terbagi kedalam tiga aspek yaitu aspek sikap (spiritual dan sosial), aspek pengetahuan dan aspek keterampilan. Untuk penilaian aspek sikap dapat dilakukan dengan teknik observasi, penilaian diri, teman sejawat dan jurnal.

Untuk penilaian aspek pengetahuan menggunakan instrumen tes tulis maupun lisan dan penugasan. Sedangkan penilaian aspek keterampilan menggunakan tes praktik, proyek dan portofolio. Dipaparkan dari hasil wawancara dengan bapak Nurkholis, M. Pd. I terkait dengan evaluasi: "Penilaian atau evaluasi pada kurikulum 2013 ini sangat berberda dengan penilaian kurikulum-kurikulum sebelunnya mbak. Karena peniliannya sulit mbak, njerimet. Ada tiga aspek dalam penilaian kurikulum 2013 ini yaitu sikap, pengetahuan dan keterampilan dan itu semua harus disajikan secara utuh dan proporsional, sesuai dengan kompetensi inti yang telah di tentukan. Lah... untuk mengetahui nilai dari setiap aspek itu ada formatnya sendiri-sendiri mbak, mulai dari kompetensi sikap (spiritial dan sosial) itu nilainnya dari observasi, penilaian diri, penilaian antar teman sejawat dan jurnal. dari form penilaian observasi saja dari sosialnya kan ada tujuh, itu semuanya dinilai jadi di perinci lagi ada form penilaian observasi sikap disiplin, kejujuran, tanggung jawab, toleransi, gotong royong, santun dan percaya diri itu saja masing-masing ada skornya. sedangkan untuk mengetahui penialian pengetahuan itu pakek instrumen tes bisa tulis bisa lisan dan penugasan 
terakhir penilaian keterampilan ada tes praktik, proyek dan portofolio. Itu rumit dan sulit mbak misal ya mbak penilaian sikap, dari sikap itu di perinci dari kejujurannnya, kedisiplinannya, tanggung jawab, toleransi, gotong royong, santunnya, dan rasa percaya diri itu ada rumus-rumusnya, seperti di komputer ini mbak" ( Nurkholis, Kepala Sekolah MTs Nurul Hikmah, Wawancara terbuka, Tonjong, 23 Oktober 2017).

Penilain dilakukan saat proses belajar berlangsung, setelah pembelajaran, ujian tengah semester dan ujian akhir semester. Guru mata pelajaran aqidah akhlaq mengalami kesulitan dalam penilaian dikarenakan guru sibuk dengan penilain yang mana format setiap penilaian berbeda dan terdapat penskoran, guru mata pelajarn aqidah akhlaq tersebut takut apabila lebih terfokus pada penilaiannya dan kompetensi dasar yang harus dicapai tidak dapat terpenuhi.

Berikut ungkapan oleh guru mata pelajaran Akidah Akhlak kelas VIII, yaitu bu Munisah, S. Pd. I sebagai berikut: "Penilaian saya ambil dari tugas-tugannya, juga ada nilai ujian tengah semester (UTS) dan lagi masih ada nilai yang diambil dari ujian akhir semester (UAS) atau ujian kenaikan kelas (UKK). jadi menurut saya kurikulum 2013 ini memang bagus karena pendekatannya sendiri menggunakan pendekatan ilmiah, tetapi membuat guru repot dengan penilaiaannya akhirnya kompetensi yang harus dicapai tidak terpenuhi. Karena guru sibuk menilai muridnya. Itu format penilaiiannya sudah banyak untuk setiap sikap di tambah lagi ini per- anak, jadi banyak sekali mbak yang perlu dinilai. Pusing mbak kalau dibawa pusing, makanya saya benar-benar menikmati hal ini agar tidak begitu pusing" ( Munisah, Guru Akidah Akhlak MTs Nurul Hikmah, Wawancara nonformal, Tonjong, 16 November 2017).

Hal serupa juga diungkapkan oleh bapak Nurrohman, S. Pd. I sebagai berikut : "Penilaian itu dilakukan selama proses pembelajaran, setelah proses pembelajaran, ulangan harian, ulangan tengah semester dan ulangan akhir sekolah. Dalam penilain proses saya rasa guru di MTs Nurul Hikmah ini menggunakan instrumen yang sama karena kesepakatan dan menyeragamkan penilaian oleh guuru-guru. Ya dinilai tentu aspek sikap, pengetahuan dan keterampilannya. Begitu mbak" ( Nurrohman, Guru Akidah Akhlak MTs Nurul Hikmah, Wawancara nonformal, Tonjong, 17 Nop 2017).

Sedangkan hasil observasi oleh peneliti yang dilakukan di MTs Nurul Hikmah bersamaan dengan bu Munisah, S. Pd. I yang sedang menilai siswa anak kelas VIII sebagai berikut: Pada pertemuan pertama bu Munisah, S. Pd. I melakukan penilaian diskusi dikelas VIII, dengan membagi 4 kelompok kecil dan setiap kelompok terdiri dari 4-5 siswa yang terhitung dari no urut apsen karena peserta didik dikelas VIII berjumlah 23 siswa. Beliau membawa jurnal penilain di mana jurnal tersebut berupa daftar nama siswa kelas VIII dan memberikan penilaian bagi semua siswa. Siwa yang aktif, siswa yang memperhatikan, siswa yang bertannya, siswa yang bermain, siswa yang tidak memperhatikan. Serta penilain setelah proses dimana guru memberikan tugas pada peserta didik untuk dikerjakan diluar jam sekolah. Sedangkan pada pertemuan kedua melakukan penilain dengan bermain peran terkait materi akhlaq tercela Ananiyah, putus asa, ghadhab dan tamak. Kelompok satu berjudul ananiyah, kelompok dua berjudul putus asa, kelompok tiga berjudul ghadhab, kelompok empat berjudul tamak. 
Penilaian di dapatkan ketika proses kegiatan belajar mengajar berlangsung dengan mengamati semua murid. Berikut merupakan teknik dan instrumen dalam penilain yang dilakukn oleh guru aqidah akhlaq kelas VIII di MTs Nurul Hikmah yang diimplementasikan dari buku pedoman guru terbitan kementerian Agama, sebagai berikut:

\section{a. Nilai Afektif}

Nilai afektif didapatkan berdasarkan teknik penilaian dengan cara meminta peserta didik untuk mengemukakan kelebihan dan kekurangan dirinya dalam konteks pencapaian kompetensi. Instrument yang digunakan berupa lembar penilaian diri.Penilaian afektif pada materi akhlaq tercela riya' dan nifaq dikelas VIII MTs Nurul Hikmah sesuai dengan buku panduan guru Kemenag dengan menggunakan huruf ( $A, B, C$ dan $D)$. Untuk penilain afektif dengan menggunakan teknik penilain diri ini, peneliti hanya mengambil satu sampel siswa bernama Muhammad Al-Faris kelas VIII MTs Nurul Hikmah yang peneliti dapatkan dari hasil terjun langsung dengan bantuan dari bu Munisah, S. Pd. I selaku guru aqidah akhlaq kelas VIII, sebagai berikut:

\section{Nama Peserta Didik : Muhammad Al-Faris \\ Kelas/Semester : VIII B/1 \\ Standart Kopetensi : Menolak perilaku tercela \\ Kopetensi Dasar : : : Ananiyah, putus asa, ghadhab dan tamak}

Indikator

1) Menjelaskan pengertian perilaku ananiyah, putus asa, ghadhab, dan tamak

2) Menunjukkan dalil naqli dan aqli terkait perilaku ananiyah, putus asa, ghadhab, dan tamak

3) Memahami macam-macam perilaku ananiyah, putus asa, ghadhab, dan tamak

4) Mengidentifikasi bentuk-bentuk perilaku perilaku ananiyah, putus asa, ghadhab, dan tamak

5) Menyajikan data dan fakta serta sumber tentang perilaku ananiyah, putus asa, ghadhab, dan tamak

6) Memahami dampak negatif dari perilaku ananiyah, putus asa, ghadhab, dan tamak
Teknik Penilaian
: Penilaian Diri
Penilaian
: Peserta Didik

Tabel 1. Lembar penilaian dari kelas VIII MTs Nurul Hikmah tahun ajaran 2017/2018 (Munisah, Guru maple akidah akhlak kls VIII, Dokumentasi, tahun ajaran 2017/2018, 19 November 2017)

\begin{tabular}{|c|c|c|c|c|c|c|}
\hline No & Perilaku & selalu & sering & Jarang & $\begin{array}{c}\text { Tdk } \\
\text { pernah }\end{array}$ & Skor \\
\hline 1 & $\begin{array}{l}\text { Memperdulikan Teman Yang Dalam } \\
\text { Kesusahan }\end{array}$ & $\sqrt{ }$ & & & & 4 \\
\hline 2 & $\begin{array}{l}\text { Tidak Mencontek Dalam } \\
\text { Melaksanakan Tugas }\end{array}$ & $\sqrt{ }$ & & & & 4 \\
\hline 3 & $\begin{array}{l}\text { Berperangsangka Baik Kepada Allah } \\
\text { Dan Mahkluknya }\end{array}$ & $\sqrt{ }$ & & & & 4 \\
\hline 4 & $\begin{array}{l}\text { Kembali Berusaha Setelah } \\
\text { Mendapatkan Kegagalan }\end{array}$ & $\sqrt{ }$ & & & & 4 \\
\hline 5 & Berwudhu Apabila Sedang Marah & & & $\sqrt{ }$ & & 2 \\
\hline
\end{tabular}




\begin{tabular}{cllc}
\hline 6 & $\begin{array}{l}\text { Memaafkan Kesalahan Orang Lain } \\
\text { Bersodaqoh Kepada Orang Yang } \\
\text { Memerlukan }\end{array}$ & $\sqrt{ }$ & 3 \\
\hline $\begin{array}{l}\text { Tidak Membeli Barang-Barang Yang } \\
\text { Tidak Perlu }\end{array}$ & $\sqrt{ }$ & 3 \\
\hline Jumlah Skor & A \\
\hline Nilai & Nilai 25-32 = A (Sangat baik) \\
Nilai 17-24 =B (Baik) \\
Keterangan; \\
Nelailu=4, Se-16 =C (Cukup) \\
Narang=2, Tidak pernah=1
\end{tabular}

b. Nilai Kognitif

Nilai kognitif di MTs Nurul Hikmah yang dilakukan oleh guru mata pelajaran aqidah akhlaq didapatkan berdasarkan nilai ulangan harian, nilai ujian tengah semester (UTS) dan nilai ujian kenaikan kelas (UKK). Ulangan harian adalah alat untuk mengukur kemampuan siswa untuk kompetensi dasar tertentu. Siswa disebut kompetensi jika mencapai kriteria ketuntasan minimal (KKM). Bagi siswa yang tidak mencapai kriteria ketuntasan minimal tersebut wajib mengikuti remedial. Ulangan tengah semester dilaksanakan setelah pembelajaran mencapai standar kompetensi tertentu, dengan memberikan seperangkat soal mengenai standard KD.

Ulangan tengah semester dilaksanakan satu kali dalam setiap semester Ulangan akhir semester adalah alat tes untuk mengukur kemampuan siswa untuk beberapa kompetensi dasar dalam satu semester. Nilai UAS tidak ada batas ketuntasan minimal, sehingga tidak ada remedial. UAS merupakan evaluasi hasil. Materi UAS terdiri dari seluruh KD dalam satu semester yang ditunjuk sekolah pada akhir semester. Pelaporan hasil ujian semester akan digabung dengan ratarata ujian blok dalam satu semester yang hasilnya berupa raport.

c. Nilai Psikomotor

Sedangkan nilai Psikomotor diperoleh oleh guru mata pelajaran aqidah akhlaq pada amteri akhlaq tercela dengan bermain peran (Role Playing). Model pembelajaran ini bertujuan untuk mengeksplorasi perasaan peserta didik, mentransfer dan mewujudkan pandangan mengenai perilaku, nilai dan persepsi peserta didik, mengembangkan keterampilan (skill) pemecahan masalah dan tingkah laku, dan mengeksplorasi materi pelajaran dengan cara yang bervariasi.

Tabel 2. Lembar penilaian psikomotorik bermain peran kelas VIII B MTs Nurul Hikmah tahun ajaran 2017/2018((Munisah, Guru mapel akidah akhlak kls VIII, Dokumentasi, tahun ajaran 2017/2018, 19 November 2017).

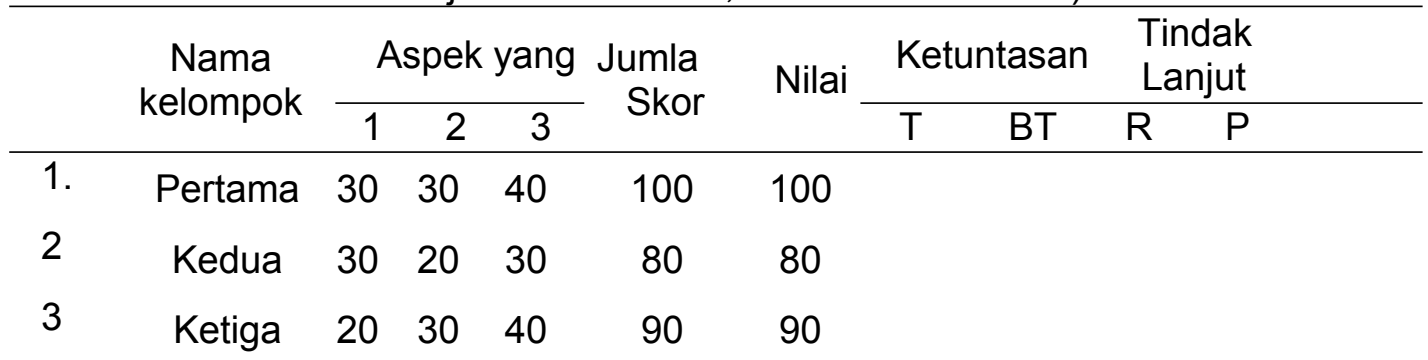




\begin{tabular}{ccccccc}
4 & Keempat & 30 & 30 & 30 & 90 & 90 \\
5 & Kelima & 30 & 20 & 30 & 80 & 80 \\
\hline
\end{tabular}

Keterangan:

T: Tuntas mencapai nilai ....( disesuaikan dengan nilai $\mathrm{KKM}=78$ )

BT: Belum Tuntas jika nilai yang diperoleh kurang dari nilai KKM

R: Remedial

$\mathrm{P}$ : Pengayaan

\section{Aspek dan Rubrik Penilaian}

1. Kejelasan dan kedalaman informasi

a) Jika kelompok tersebut dapat memberikan penjelasan dan kedalaman informasi lengkap dan sempurna, skor 30

b) Jika kelompok tersebut dapat memberikan penjelasan dan kedalaman informasi lengkap dan kurang sempurna, skor 20

c) Jika kelompok tersebut dapat memberikan penjelasan dan kedalaman informasi kurang lengkap, skor 10

2. Penghayatan yang diperlukan

a) Jika kelompok tersebut berperan sangat aktif dalam bermain peran, skor 30

b) Jika kelompok tersebut berperan aktif dalam bermain peran, skor 20

c) Jika kelompok tersebut kurang aktif dalam bermain peran, skor 10

3. Kerja Sama

a) Jika kelompok tersebut dapat bekerja sama dengan sangat baik, skor 40

b) Jika kelompok tersebut dapat bekerja sama dengan baik, skor 30

c) Jika kelompok tersebut kerjasamanya kurang baik, skor 20

d) Jika kelompok tersebut kerjasamanya tidak baik, skor 10

Nilai $=a+b+c$

Dari paparan evaluasi pada pembelajaran Akidah Akhlak kelas VIII MTs Nurul Hikmah yang diterapkan oleh para guru mata pelajaran Akidah Akhlak, dapat ditarik kesimpulan bahwa, penilaian kurikulum 2013 meliputi tiga aspek yaitu, aspekafektif, aspek kognitif dan aspek psikomotorik sebagaimana tertuang dalam konsep kurikulum 2013.

\section{KESIMPULAN DAN SARAN}

Berdasarkan penelitian yang dilakukan di MTs Nurul Hikmah bagi siswa kelas VIII di MTs Nurul Hikmah terkait implementasi kurikulum 2013, dapat ditarik kesimpulan:

1. Perencanaan untuk guru mata pelajaran aqidah akhlak menyangkut penyusunan silabus dan rencana pelaksanaan pembelajaran (RPP). Untuk silabus mata pelajaran aqidah akhalak sudah disiapkan oleh Kementerian Agama tetapi pemerintah juga memberikan kebebasan bagi pihak sekolah atau guru mata pelajaran untuk mengembangkan silabus sesuai dengan kebutuhan sekolah dan 
peserta didik. Sedangkan untuk rencana pelaksanaan pembelajaran (RPP) guru wajib menyusun RPP secara mandiri yang didalamnya terdapat rincian penggunaan pendekatan saintifik yakni mengamati, menanya, mengumpulkan informasi, mengolah dan mengkomunikaskan. Penyusunan RPP mempertimbangkan teknologi informasi dan komunikasi sesuai dengan situasi dan kondisi MTs Nurul Hikmah.

2. Pelaksanaan pembelajaran aqidah akhlak menggunakan metode ceramah, diskusi, presentasi tanya jawab. Akan tetapi metode ceramah masih dominan digunakan. Dimana metode-metode tersebut relevan digunakan dala pendekatan saintifik. Karena didalam buku pedoman guru aqidah akhlaq kelas VIII terbitan Kemenang dalam pemebalajarannnya sesuai dengan pendekatan saintifik dan hal tersebutditerapkan oleh guru aqidah akhlaq berarti guru juga tidak susah dalam pembelajaran berbasis kurikulum 2013 tersebut.

3. Evaluasi dalam pembelajaran aqidah akhlak dilakukan dalam tiga hal yakni, pada saat pembelajaran berlangsung, setelah pembelajaran dan evaluasi ujian tengan dan kenaikan kelas. Dalam evaluasi tersebut sudah mencakup aspek sikap, pengetahuan dan ketarampilan. Dimana dalam penilaian aspek sikap di MTs Nurul Hikmah menggunakan teknik penilaian diri, untuk penilaian pengetahuan MTs Nurul Hikmah menggunakan tes lisan dan tulis yang didapat dari ulangan harian, ujian semester dan ujian tengah semster dan ujian akhir semester ditambah dengan tugas- tugas yang diberikan kepada siswa-siswi kelas VIII. Dari Evaluasi yang dilakukan juga menghasilkan Perkembangan peserta didik yang berbeda ketika masih menggunakan sisitem KTSP dibandingkan ketika sekolah sudah mulai mengimplementasi kurikulum 2013 terkait pembelajaran aqidah akhlaq bagi siswa kelas VIII di MTs Nurul Hikmah yakni peserta didik menjadi lebih aktif dalam mencari tahu atau ber eksperimen karena pembelajaran yang menyenangkan, serta dapat meningkatkan pemahaman dan penguasaan materi akhlaq yakni, mengenai sikap ananiyah, putus asa, ghadhab dan tamak oleh peserta didik, dan juga dengan kurikulum 2013 peserta didik tidak hanya dapat menguasai materi namun juga dapat menyeimbangkan akhlaq atau sikap dan keterampilan yang dimilikinya untuk dikembangkan dalam kehidupan sehari-hari.

\section{SARAN}

Berdasarkan kesimpulan yang telah dikemukakan, maka peneliti dalam kesempatan ini menyapaikan beberapa saran sebagai berikut:

4. Guru tetap aktif dalam mengikuti kegiatan yang dilakukan oleh pemerintah maupun sekolah seperti, penataran, workshop yang terkait dengan kurikulum 2013. Hal ini dikarenakan agar semua guru mengerti dan memahami secara mendalam bagaimana mengimplementasikan kurikulum 2013 sesuai dengan prosedur pemerintah.

5. Semangat untuk belajar serta metode dan penilaian yang digunakan dengan konsisten dalam mengimplementasikan kurikulum 2013 terkait dengan perencanaan, pelaksanaan dan evaluasinya agar tercipta siswa yang tidak hanya cerdas saja tapi juga memiliki akhlak yang baik. 


\section{DAFTAR PUSTAKA}

Kusuma, Cahaya,(2013), Pengembangan Kurikulum 2013 Analisis Pengembangan Komponen - Komponen Kurikulum 13 Pada Bahan Uji Publik Kurikulum 2013.

Nuh, Muhammad. (2013), Pengembangan Kurikulum 13, Jakarta Kementrian Pendidikan dan Kebudayaan.

Moleong, Lexi, J. (2004) Metode Penelitian Kualitatif, Bandung : Remaja Rosdakarya.

Moleong, Lexi, J. (2013) Metode Penelitian Kualitatif, Edisi Revisi. Bandung : Remaja Rosdakarya.

Fadillah, M. (2014), Implementasi Kurikulum 2013 Dalam Pembelajaran SD/MI, SD/MTS, dan SMA/MA, Yogyakarta : Ar ruzz.

Judistira K. Gama, (2008), Dasar dan Proses Penelitian Sosial, Bandung : Primaco Akademika.

Sukmadinata, S.N. (2009) Metode Penelitian Pendidikan. Bandung : Rosdakarya.

Nawawi, Hadari (1993), Metode Penelitian Sosial, Yogyakarta ; Gajah Mada University. 